\title{
ADAPTATION OF MEDIBALL EDUCATION FOR THE RESOURCE ACTIVATION OF UNIVERSITY STUDENTS
}

\author{
Tímea Boda * \\ Institute of Management and Organisation Sciences, University of Debrecen, Hungary \\ https://doi.org/10.47833/2021.1.ART.003
}

\begin{abstract}
Keywords:
resource activation, skills

development, higher

education, MediBall,

personal effectiveness

$\begin{array}{lc}\text { Article history: } \\ \text { Received } & \text { 12 Marc } 2021 \\ \text { Revised } & \text { 18 Marc } 2021 \\ \text { Accepted } & 3 \text { Apr } 2021\end{array}$
\end{abstract}

\begin{abstract}
The aim of the study is to present a young sport, MediBall. The innovative method and form of movement catalyses the skills needed to activate resources and can thus be an excellent accompaniment in supporting students' personal effectiveness during their university studies. Research shows that MediBall strengthens among others the creativity, self-knowledge, communication, resilience, stress relief and activity of students. At the same time, Mediball gives its practitioner a significant sense of success and joy.
\end{abstract}

\section{Introduction}

Students' ability to activate resources can, on the one hand, determine their performance during their university studies and, on the other hand, affect their general well-being. From the point of view of the students' present and future, the extent to which he or she is able to take advantage of his or her opportunities as a university citizen and, last but not least, how joyful and positive emotional this life will be is important. Defining attitudes and habit mechanisms during their university studies can also predict the potential of a young professional to start his or her career or profession. It is the task, responsibility and in the interest of universities not only to equip students with the appropriate expertise, but to prepare the young professionals with the ability to enter the changing labour market in a resilient, motivated way and with full knowledge of his/her personal resources, avoiding the agespecific "gate-opening panic". The key to the student's energy and costly return on investment from the parent and the university is the ability to utilize the students' personal resources in addition to their professional knowledge.

\subsection{Resource activating of university students through positive emotions}

Resource activation is the recognition of our own resources in a challenging situation to help us manage our difficulties more effectively. These resources may vary from situation to situation. According to Deubner (2020), resources are: “... the life resources of body and soul." [1] According to Gutscher (1998), resources refer to the neurologically coded needs we are born with that ensure our physical and mental health and overall our survival. Any experience that contributes to meeting these needs can be considered as a resource. [1] According to Nestmann (1996), something becomes a real resource when a person is able to apply it to reach his or her goals. [2]

Recognizing resources means being aware of what is at one's disposal and what the factors are that underlie and support a person in achieving the goals. [3] However, recognizing the factors mentioned above requires, on the one hand, conscious attention and, on the other hand, an accompanying attitude that enables one to recognize the positive aspects of the outside world. [1] Resources in a person are internal resources, such as abilities/skills, attributes, tendencies to be interested,

\footnotetext{
* Kapcsolattartó szerző. Tel.: +36 203972355

E-mail cím: boda.timea@econ.unideb.hu
} 
knowledge, attitude [4] and external resources that are available in the individual's environment, such as social network, work, infrastructure, nature, culture.

For the sake of our inner homeostasis, both our mental and our physical resources are crucial. According to Grawe, spiritual resources can be defined as the positive energy and life source needed to meet people's basic needs. They are catalysts that can determine our positive happinessunhappiness balance; our attachments; our goals and the feeling of finding meaning in our actions; they determine one's self-respect. [5]

Among others, the following resources, can help to support spiritual needs:

- activities that strengthen a person's self-respect; recognition and esteem in everyday life

- active life management and adequate leisure and appropriate framework for orientation

- meaningful relationships and social support and cooperation

- positive feelings in everyday life; joy, cheerfulness, pride and happiness [5]

Achor (2015) studied student resource activation in stressful situations at Harvard University. $\mathrm{He}$ found that otherwise intelligent students, instead of building their social network, the resource that can most stably enhance their happiness and success they decompose it. Social contacts are a resource that also accounts for an excellent life quality and low stress levels. [6] Our physical resources ensure our physical survival. These resources are especially needed in stressful situations. It is in difficult situations that we care less about our physical resources. We sleep less; we have no motivation and no strength to move; we eat anything that improves our mood while not serving our health; we do not pay attention to adequate water intake or we neglect the role of breathing in relieving stress. According to a Belgian-Canadian research paper of 2002 our breathing rhythm may be responsible for up to $40 \%$ of our emotional reactions. [7] Thus correct breathing is a resource that we typically do not know enough about, or we do not use it consciously as a resource; except perhaps people who are exercising high-level yoga or meditation. According to Mcintosh, physical exercises can reduce the amount of cortisol in the body, which also reduces the risk of stress-related chronic diseases; exercising helps the brain produce norepinephrine and serotonin, what makes us feel happier and more relaxed. [7] Overall, movement is a physical resource that also has a positive effect on our spiritual needs.

According to Fredrickson (2015), a positive life philosophy contributes to becoming more open towards our own perceptions, thereby solving problems more creatively. Our positive thinking can renew our ideologies and revitalize our mental condition. [8] According to Gollwitzer et al. (1996), the difficulty of this process also lies in the fact that positive views fit into our cognitive representation of ourselves and the World, so-called cognitive schemas, and therefore do not appear in everyday life. In contrast, negative information is more glaring, they fit less into our cognitive schemas, thus it also takes more time to process them - therefore they stay longer in our memories. [9] Achor (2015) examined 1,600 high-performing undergraduates at Harvard. The aim of the research was to find out what makes some students outstanding, while others perform only average or less. Achor summarized the results of the research in the following 7 principles. These principles help students to develop their abilities, to be able to take advantage of their opportunities, to be effective, and to be able to overcome their bad habits:

1. The Happiness Advantage, happiness as a competitive advantage - happiness enables a person to build capital out of a positive attitude, it develops performance

2. The Fulcrum and the Lever - the ability to change attitude in order to give strength to fulfillment and success

3. The Tetris Effect - the ability to notice patterns that help seize and live opportunities

4. Falling Up - finding a path of thought that leads out of crisis, out of anxiety and allows to increase a sense of happiness

5. The Zorro Circle - even in a distressed situation one should be able to control emotions and think rationally

6. The 20-Second Rule - our energy economy plays a very important role in the ability to leave old bad habits and create new ones

7. Social investment - the ability to devote energy to strengthening and nurturing our relationship capital even in difficult situations. [6] 
The impact of the Bologna Process on student relations is significant. Relationships among students have loosened, the number of platforms where students have supported each other by building and living a close professional-friendly community has decreased. The relationships contributed to the social support that is necessary for students to meet their spiritual needs and contributed also to the community experience that is one of the defining elements of well-being. A living community is the best test of our resources. It is a driving force that, with its secure atmosphere, has a positive and encouraging effect in testing, mapping, and developing personal resources of students. Achor defined happiness as a competitive advantage in students' lives. The basis of being a student is the quality and joyful relationships through which students also learn the art of collaboration. Today's higher education must therefore seek to patch the holes caused by the Bologna Process.

Aristotle's concept of eudaimonia does not only refer to happiness, but to fulfilment and prosperity. This content also appears in Seligman's definition of happiness. According to him, those who find joy, commitment and meaning in their lives live the fullest possible lives. [10] A positive attitude is thus a resource that has a beneficial effect as a competitive advantage on our personal effectiveness. [11] The skills and competencies required for this can be developed in many ways. Goleman's (2018) research, for example, demonstrates that meditation, in addition to helping to relieve stress and mental resilience, helps to frame our less useful thought pattern in a positive direction. [12] Bagdy (2014) refers to "vitality generators" as modes of struggle that can usually be developed through forms of activity, movement, and conscious use of mental and spiritual "trainings". Relaxation is also a "vitality generator" that, in addition to relieving physical and mental tensions, helps to get rid of our bad attachments. [13] A 2019 study showed that MediBall, based on player experience, improves the physical and mental balance in $94.9 \%$ and helps to leave bad habits in $87.3 \%$ of the cases. Mediball is able to build a system of habits in a player's life that has a positive effect on the health structures formulated by the WHO. [14] Huppert and So from the University of Cambrige measured the state of happiness in 23 Member States of the European Union. Their definition of happiness is consistent with Seligman's theory of well-being. To reach the state of happiness an individual should have the three basic and three of the six additional traits:

Basic traits: positive emotions, mental immersion, intellect

Additional traits: self-esteem, interest, goal, optimism, flexibility, positive relationships

Results of the research show that $33 \%$ of Danish people live in happiness. The worst results were measured in Russia; $6 \%$ said that they are happy. Hungary ranks $6^{\text {th }}$ from behind, less than $10 \%$ of the population stated that they live in happiness. [15]

According to Davidson and Begley (2013), our emotional life determines how we respond to our life experiences. Emotional life thus has an impact on activating our resources. Our emotional style and brain connection are objectively measurable. [16] [17] [18] Our emotional style can be regarded as the building blocks of our emotional style. Building on the findings of modern brain research, Davidson and Begley (2013) interpret emotional style in the following six dimensions:

1. Resilience

2. Outlook

3. Social intuition

4. Self-awareness

5. Sensitivity to context

6. Attention [19]

The six dimensions are similar to the principles of Seligman, Achor, and Grawe at several points. These principles appear as an expectation towards young graduates in the selection and recruitment process of organizations. It is therefore crucial, also for the younger generation, to incorporate attractive methods into university education that focus on the development of skills related to the above principles, in order to map and continuously develop students' own resources. One such new method is MediBall, which develops areas of ability that affect both mental and physical needs at the same time.

\subsection{Mediball: an innovative method of resource activation}

MediBall is a modern sport and movement art form that is characterized by the elegance, creativity and aesthetics of human intelligence at the individual and team level. It is similar to Chinese 
Rouliqiu, which builds on the circular movements of traditional Tai Chi. István Szilágyi, professional director of Mediball has further developed this sport and has added the syncron method, which is the dominant character the Hungarian Mediball. MediBall is a movement ball game based on special soft, circular movements, but at the same time validating the natural dynamics of the body, which provides a great opportunity to develop mental and physical resilience and performance. During practice, players create mental, physical, and emotional synchronicity. MediBall is played with a 26 $\mathrm{cm}$ diameter silicone racket and a rubber ball filled with $55 \mathrm{~g}$ of sand. The versatility of the game is that it can be exercised individually, in pairs and in teams.

The form of movement can be used in fixed form practice ("kata") or in both creative "free" exercises and matches. MediBall was launched in Hungary in 2008 under the professional leadership of Master István Szilágyi. The Hungarian MediBall Association was established in 2015. MediBall groups operate in nearly 30 cities in Hungary. [20]

\section{Methodology}

In 2019, $118(n=118)$ MediBall players participated in the research; that covers $40 \%$ of all players. The age of the 118 players ranges from 15 to 68 years; the gender distribution is 42 men and 76 women. Sample selection was random in the research, participation was voluntary. The relationship between MediBall and personal effectiveness has not been researched and the adaptation of MediBall in higher education has not been studied before. The questions of the questionnaire focused on the experience of players who have been exercising MediBall for many years. An important variable in the measurement is who has played MediBall for how many years and with what frequency. $5.9 \%$ of players exercise Mediball since less than half a year, $6.8 \% 1$ year, $8.5 \% 2$ years, $17.8 \% 3$ years, $7.6 \% 4$ years, $7.5 \% 5$ years and $45.8 \%$ for more than 5 years. $14.4 \%$ of the players play MediBall monthly, $28.8 \%$ once a week, $19.5 \%$ twice a week, $31.4 \%$ several times a week and $5.9 \%$ daily. During the quantitative empirical research, the author processed the selfreport questionnaires with SPSS 20 software.

\section{Results}

The experience of the 118 main MediBall players who completed the questionnaire are summarized in the table below.

\begin{tabular}{|l|l|c|c|c|c|}
\hline \multicolumn{1}{|c|}{$\begin{array}{c}\text { Based on my } \\
\text { experience, Mediball is } \\
\text { improving me in the } \\
\text { following areas... }\end{array}$} & $\begin{array}{c}\text { not at all } \\
\text { typical } \\
\%\end{array}$ & $\begin{array}{c}\text { slightly } \\
\text { typical } \\
\%\end{array}$ & $\begin{array}{c}\text { typical } \\
\%\end{array}$ & $\begin{array}{c}\text { totally } \\
\text { typical } \\
\%\end{array}$ \\
\hline 1. & self-expression & 1,7 & 11,9 & 47,5 & 39,0 \\
\hline 2. & creativity &, 8 & 9,3 & 39,0 & 50,0 \\
\hline 3. & success experience & 0 & 8,5 & 47,5 & 44,1 \\
\hline 4. & relaxation &, 8 & 6,8 & 35,6 & 56,8 \\
\hline 5. & more regul breathing &, 8 & 11,0 & 45,8 & 42,4 \\
\hline 6. & balance & 0 & 3,4 & 44,1 & 52,5 \\
\hline 7. & orderliness &, 8 & 8,5 & 39,8 & 50,8 \\
\hline 8. & feeling happy & 0 & 6,8 & 28,0 & 65,3 \\
\hline 9. & flow-experience &, 8 & 12,7 & 39,0 & 47,5 \\
\hline 10. & calms me down & 0 & 8,9 & 38,1 & 55,1 \\
\hline 11. & feeling of silence & 0 & 3,4 & 45,8 & 45,8 \\
\hline 12. & attention and & & & 31,4 & 65,3 \\
\hline 13. & imagination &, 8 & 13,6 & 46,6 & 39,0 \\
\hline 14. & game experience & 0 & 6,8 & 28,8 & 64,4 \\
\hline
\end{tabular}




\begin{tabular}{|c|l|c|c|c|c|}
\hline 15. & $\begin{array}{l}\text { communication and } \\
\text { collaboration }\end{array}$ &, 8 & 6,8 & 47,5 & 44,9 \\
\hline 16. & self-knowledge &, 8 & 14,4 & 42,4 & 42,4 \\
\hline 17. & self and body awareness & 0 & 12,7 & 32,2 & 55,1 \\
\hline 18. & $\begin{array}{l}\text { Physical and mental } \\
\text { balance }\end{array}$ & 0 & 5,1 & 41,5 & 53,4 \\
\hline 19. & experiencing wholeness &, 8 & 12,7 & 43,2 & 43,2 \\
\hline 20. & time management & 1,2 & 28,8 & 52,5 & 16,9 \\
\hline 21. & $\begin{array}{l}\text { in dealing with stress in a } \\
\text { competitive situation }\end{array}$ & 5,9 & 13,6 & 53,4 & 27,1 \\
\hline
\end{tabular}

Table 1: Based on the experience of MediBall players, MediBall develops the following areas

If we examine the results in terms of the emotional style dimensions of Davidson and Begley (2013), the results show that MediBall has a developing effect on the "self-awareness" dimension $84.8 \%$ of players say that the game improves their self-knowledge, $87.3 \%$ say it improves their self and body awareness and $86.5 \%$ say that MediBall develops their self-expression. Considering the "Flexibility" and "Context Sensitivity" dimensions, we can see that MediBall has a positive effect on equilibrium. MediBall helps $96.6 \%$ to be balanced, $92.4 \%$ of players say it helps them relax, while $96.7 \%$ say it supports concentration and attention and $80.5 \%$ say it helps them to cope with stress. Examining the dimension of 'Social Intuition', the results are outstanding; $92.4 \%$ of players say that MediBall develops skills related to communication and collaboration. Examining the "Attitude" dimension and Grawe's resources to support spiritual needs, such as joy, positive feelings in everyday life and happiness, the players stated that MediBall has a distinctly developing effect on them in the following areas: $93.2 \%$ said it gives a strong game experience; $91.6 \%$ said it gives a sense of success, $93.3 \%$ said the game is a real pleasure for them and $96.5 \%$ said Mediball helps them experience the flow state.

Overall, the results show that MediBall as a resource supports the spiritual needs articulated by Grawe (1998), and Mediball - as an active form of movement - has a positive effect on physical needs.

The chart below clearly shows that MediBall appears to players as a complex resource that has become dominant on many fronts of their lives.

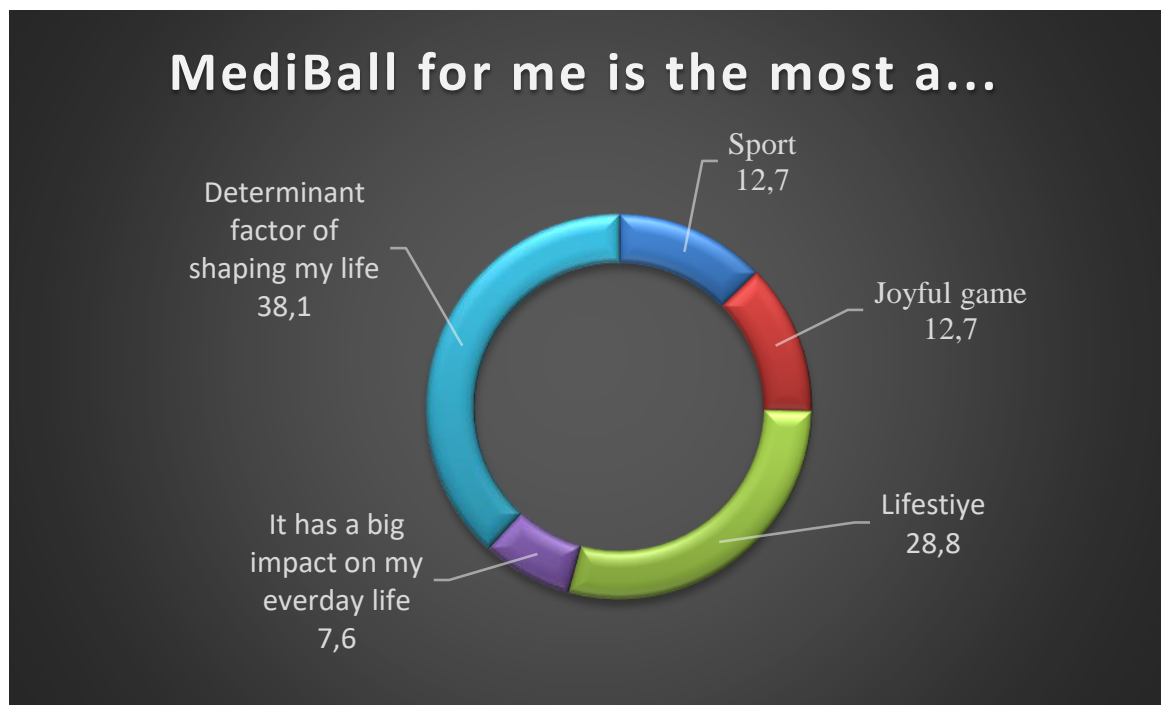

Diagram 1: The role and significance of Mediball in the lives of players (\%) 
According to Siegmund (2011), all people are able to activate their resources, but it is not efficient to wait passively for resources to be activated by an external force. [21] Mediball is an active resource catalyst that is capable developing the skills that are essential to personal effectiveness on multiple fronts.

\section{Conclusions}

The results of the research confirm that MediBall is an exciting method that is also an opportunity to develop the resources of university students. Today's young generation is progressing fast, they want to meet their needs immediately, they do not like to wait; they want to harvest the fruits of their work right away. MediBall, as a young form of movement, is a tool of development for students' resources, which, in addition to providing an immediate experience of success and happinessfor its practitioner, helps to build and strengthen social relationships at the university. The real uniqueness of the game lies in the fact that physical and mental feelings are born at the moment the player begins to practice and the experiences gained here can be incorporated into the lives of students as a real, yet player-like resource. MediBall develops, gamifies and adapts to the needs of today's young generations with the help of movement and thereby goes beyond the routine traditional development trainings provide.

\section{References}

[1] Deubner, M. - Böhme Uta Deppe - Schmitz (2020): Eröforrások aktiválása a coachniban, Miskolc Z-Press Kiadó pp.11.,44. ISBN 978-615-6167-00-2

[2] Nestmann,F. (1996): Psychosozial Beratung - ein ressourcentheoretischer Entwurf. Verhaltens-therapie and Psychosoziale Praxis, 28 (3) pp.359-376

[3] Molnár Edina (2012) Supervision in social work: experiences as a college supervisor of social worker training, Economica (Szolnok) 5, 2. különszám, pp. 29-35.

[4] Molnár Edina (2017b) Kommunikáció, meggyőzés, reklám. Alumni Kiadó, Szolnok

[5] Grawe, K. (1998): Psychologische Therapie. Göttingen: Hogrefe pp.421.

[6] Achor, S. (2015): A boldogság mint versenyelőny, Budapest Hvg Könyvek Kiadó pp.25-32. ISBN 978-963-304-2120

[7] Mcintosh, D. Horowitz, J. (2018): Stressz. A feszültségoldás pszichológiája. Budapest, Hvg Könyvek Kiadó Zrt. pp.128-129. ISBN 978-963-304-687-6

[8] Fredricson, B. (2015): A pozitív érzelmek hatalma. Budapest, Akadémiai kiadó pp.28-42 ISBN 9789630596404

[9] Gollwitzer, P.M., Bargh J. A. (1996): The psychology of action. Linking Cognition and Motivation to Behavior. New York, Guilford ISBN

[10] Seligman Martin (2008): Autentikus életöröm - A teljes élet titka. Györ, Laurus ISBN

[11] Molnár Edina (2017a) Korabeli magyar reklám és pszichológia. Alumni Kiadó, Szolnok

[12] Goleman, D. Davidson, R. (2018): A meditáció tudománya Budapest, HVG Könyv Kiadó pp. 226-232. ISBN 978963-304-550-3

[13] Bagdy Emőke (2014): Relaxáció Megnyugvás Belső BékeKulcslyuk Kiadó pp. 27-30. ISBN 978-615-800090-6-5

[14] Boda Tímea (2020): MediBall - a 21. század jellemző betegsége, a stressz kezelésének újszerü módszere, innovatív lehetőség a munkavállalók stresszkezelésében és a reziliencia fejlesztésében Szent István University Károly Róbert Campus, Gyöngyös XVII. NEMZETKÖZI TUDOMÁNYOS NAPOK ONLINE KONFERENCIA „Környezeti, gazdasági és társadalmi kihívások 2020 után” Gyöngyös Hungary June 05, pp.155. 2020 ISBN 978 615-5969-02-7 (online)

[15] Seligman Martin (2016): Flourish-élj boldogan! A boldogság és a jól-lét radikálisan új értelmezése Budapest, Akadémiai Kiadó pp.35-37. ISBN 9789630591508

[16] Molnár, Edina (2020a) The Role of the High Emotional Arousal Level in Purchasing Decisions Caused by Advertisements (August 3, 2020). SEA - Practical Application of Science, 2020, Available at SSRN: https://ssrn.com/abstract=3666009.

[17] Molnár Edina (2020b) The role of empathy, anxiety and personality in purchasing decisions caused by advertising. Annals of the University of Oradea. Economic Science, 29 (1), pp. 376-386.

[18] Molnár Edina (2020c) The role of momentary and sustained emotional arousal level in advertising-infulenced and non-influenced purhasing decisions..Cross-cultural Managament Journal, 22(1), pp. 67-78. RePEc:cmj:journl:y:2020:i:1:p:67-78

[19] Davidson J. Richard, Begley Sharon. (2013): Az agy érzelmi élete. Budapest, Akadémiai Kiadó pp. 19-26. ISBN 9789630594158

[20] Szilágyi István (2016). A MediBall leírása. Mediball. http://www.mediball.hu/jatek/453-leiras

[21] Siegmund, Besser-Cora, Siegmund Harry (2011): Wingwave coachnig, Miskolc Z-press Kiadó Kft pp. 146. ISBN 978-963-9493-56-8 